\title{
FLOATING FLEXIBLE PROTECTIVE STRUCTURE
}

\author{
${ }^{1}$ Rogachko S.I., Doctor of Engineering, Professor, \\ rostasice@ukr.net, ORCID: 0000-0001-5201-5368 \\ ${ }^{1}$ Pliasunova O.O., post-graduate student, \\ elena.margo56@gmail.com, ORCID: 0000-0003-0327-1861 \\ ${ }^{1}$ Odessa National Maritime University \\ Mechnikova str, 34, Odessa, 65029, Ukraine
}

\begin{abstract}
In the hydraulic engineering construction, structures of various purposes, as well as the shores of the seas, lakes and reservoirs, are subjected to intensive action of wind waves. Reducing the intensity of this action is an important technical problem, the solution of which will significantly increase the service term of stationary offshore structures and reduce the degree of destruction of coasts, especially those areas where settlements and recreation areas are located.

Many countries in the world have patented many design solutions for floating and flexible breakwaters designed to reduce the parameters of storm waves. They can be used for various purposes as temporary structures. This primarily relates to the construction of protective and shore protection structures in unprotected waters. The water areas of many ports of our country are reliably protected by stationary sea structures from penetrating wind waves from the sea, but in the same time the technical condition of many shore protection structures exposed to storm waves cannot be described as satisfactory. They require major reconstruction. Long coasts of the Black and Azov Seas must be protected from the destructive effects of wind waves and drifting level ice in severe winters of rare frequency by various types of shore protection structures.

The arrangement of offshore hydrocarbon deposits on the Black Sea shelf is associated with the offshore constructions at various depths. Their construction will also be carried out in conditions of the open sea. At the same time, the loss of working time, due to adverse weather conditions, will be significant, which will lead to an increase of construction term, and therefore to financial losses. For this reason, the development of new designs of non-stationary, quickly built breakwaters for temporary protection of water areas, limited in area, seems to be an important engineering task.

This paper analyzes the designs of floating and flexible breakwaters patented in various countries. Based on this analysis, a design of a flexible floating breakwater was developed, which can be successfully used to effectively extinguish the energy of wind waves in limited areas of a wavy stormy sea surface.

This design of a flexible floating breakwater is protected by the patent in our country. In order to significantly reduce the parameters of wind waves, it can be successfully used in processes of: construction of stationary protective structures; the construction of shore protection structures of various types; the arrangement of offshore hydrocarbon deposits on the continental shelf; protection of sea channels from sedimentation.

Keywords: flexible floating protective structure, floating breakwater, flexible breakwater, shore protection structures, offshore oil and gas hydraulic structures, innovative design, water area, approach channel, sea channel, wind waves.

Introduction. The main difficulties during the construction of offshore hydraulic structures in the open sea are wind waves. Since calm weather in the waters of the seas is a rare occurrence during the year, the loss of working days during the construction of hydraulic works is very significant. This applies to the construction of stationary protective and shore protection structures, and to the development of offshore hydrocarbon deposits on the continental shelf, located at great depths, where the construction of stationary protective structures is inexpedient.
\end{abstract}


The stationary shore protection structures built in our country are in unsatisfactory condition. Reconstruction of existing shore protection structures and construction of new ones involves the production of hydraulic works in the open sea. Therefore, at present, the creation of floating and flexible protective structures is of practical interest in various countries. The development of the most rational and efficient designs of floating and flexible protective structures is also relevant in Ukraine.

Analysis of recent research and publications. Reducing the construction time of any structures, including hydraulic, is an important economical problem. In the near future, our country will have to actively develop offshore hydrocarbon deposits on the Black Sea shelf belonging to Ukraine. Currently, various engineering organizations are developing projects to protect the sea shores of the Azov and Black Seas. The main force factors that destroy the coast are wind waves and drifting level ice fields. The successful construction of offshore hydraulic structures for various purposes in the open sea requires the development, testing in laboratory and natural conditions of effective and not expensive constructions of protective structures for temporary protection of limited water areas. Only after that it will be possible to introduce them into engineering practice.

A lot of designs of floating and flexible protective structures have been patented in the world. The main wave-extinguishing structural elements thereof are located directly on the surface of the water. In addition, part of the proposed designs works on the principle of seaweed, located in the thickness of the water environment.

Winds form and extend wind waves on the water surface [1]. In accordance with the classical concept of oscillations, particles of the water environment during the extension of waves make oscillatory movements around their middle position. It follows from this that in the process of wave extension over the water surface, only energy transfer is observed, and mass water transfer doesn't occur. This means that only the wave form extends over the water surface, since water particles in the wave do not participate in the translational motion.

It is known that in deep water, water particles in the waves make approximately uniform motion in closed circular orbits [2], moving at a certain speed at the tops of the ridges in the direction of wave movement, and in the troughs in the opposite direction. Entering the shallow zone, the height of the waves first increases, they become asymmetric due to an increase in the crest. Then the height of the waves decreases, and the shape of the orbits of the water particles in the wave changes to elliptical ones, which, decreasing in size with depth, do not attenuate at the bottom, that is, the process of wave spread from the wavy surface to the bottom.

Floating protective structures [3-10] are located on the surface of the water environment, where the main energy of wave motion occurs. Such structures make forced oscillations on a wavy surface. When the frequency of their own oscillations is close or coincides with the frequency of storms waves, then the phenomenon of resonance occurs. At the same time, the amplitude of the breakwater oscillations increases sharply, which contributes to a partial decrease in wave energy. In this case, the floating part of the breakwater is an additional generator of waves on a wavy surface. Waves generated by a floating breakwater contribute to the quenching of wind waves in those cases when the period of natural oscillations of the breakwater is more than the period of storms waves.

However, floating breakwaters, despite a number of advantages, have a significant drawback, which is associated with their fixation in the design position through flexible connections, as well as with an insufficient degree of quenching of wind waves. The first drawback, as shown by field tests, leads to a break in ties during the operation of hard storms. The second drawback does not allow the use of floating breakwaters instead of stationary ones, especially when protecting port water areas.

So, for example, in the 60s of the last century, on the waters of one of the Black Sea ports in the open gate range, a floating breakwater, patented in the former USSR, was installed at anchor ties [11]. Being on the water surface, the frame structure with wave-extinguishing elements was attached to the bottom by means of anchor ties. During the period of the storm, the experimental section of a breakwater repeated the profile of irregular waves, without significantly affecting the change in their parameters. As a result of the force impact of the waves, the anchor ties were broken, and the breakwater was thrown ashore. Also, such breakwaters are ineffective when exposed to long-period waves in the post-storm periods, since they are completely on the surface of the water.

Bulletin of Odessa State Academy of Civil Engineering and Architecture, 2020, no. 78, page 126-134 
Constructions of flexible protective structures proposed by various authors [12-17] are attached directly to the bottom and do not cross the free surface of the water, being constantly in vertical position. Under the influence of wind waves, they deviate from a vertical position, like seaweed growing vertically in fresh water. The wave-extinguishing elements of flexible protective structures under the influence of wind waves make elastic wavering in the water depth, thereby causing the energy of the waves to dissipate, and reducing their speed of extension over the water surface. In addition, flexible fibers made of synthetic materials help to reduce not only bottom wave velocities, but also along coastal currents, which will stimulate sediment accumulation. Thus, using these design solutions, you can protect the coast, increasing the width of the beaches. The main disadvantage of the flexible type of protective structures is the insufficient degree of quenching of wind waves on the water surface. They also cannot be used to protect port water areas.

A review of the patented construction of floating and flexible protective structures, as well as an analysis of their operation, showed that they cannot, in principle, effectively absorb the energy of wind waves throughout the water depth. For this reason, they did not find their application on the seas. Their use is possible only on lakes and reservoirs where the size of the wave parameters is much smaller than at sea. The combination of the technical features of floating and flexible protective structures in a new design solution will provide a more intense dissipation of wave energy throughout the water depth, which means it will significantly reduce the parameters of the initial storms waves.

The purpose of research. The purpose of this work is to develop an innovative design for an easily erected and not expensive floating flexible protective structures that can effectively extinguish the energy of wind waves, significantly reducing their parameters, for the temporary protection of local water areas where construction of hydraulic structures for various purposes in the conditions of open sea is underway is taken place. This construction design can also be successfully used as: temporary shore protection structures of an active type; enclosing flexible spurs to protect against the sedimentation of marine navigation channels, including approach channels.

Research methodology. The development of a floating flexible protective structure was carried out taking into account: the process of quenching of wind waves on the sea surface; water depths; trajectories of motion of fluid particles in a wave in deep and shallow water zones; physical and mechanical properties of non-woven synthetic materials; bracing the construction design of a floating flexible protective structure to the seabed.

Research results. The construction design of a floating flexible protective structure is shown in Fig. 1. It is patented by the authors of this article with a patent of Ukraine for a utility model [18].

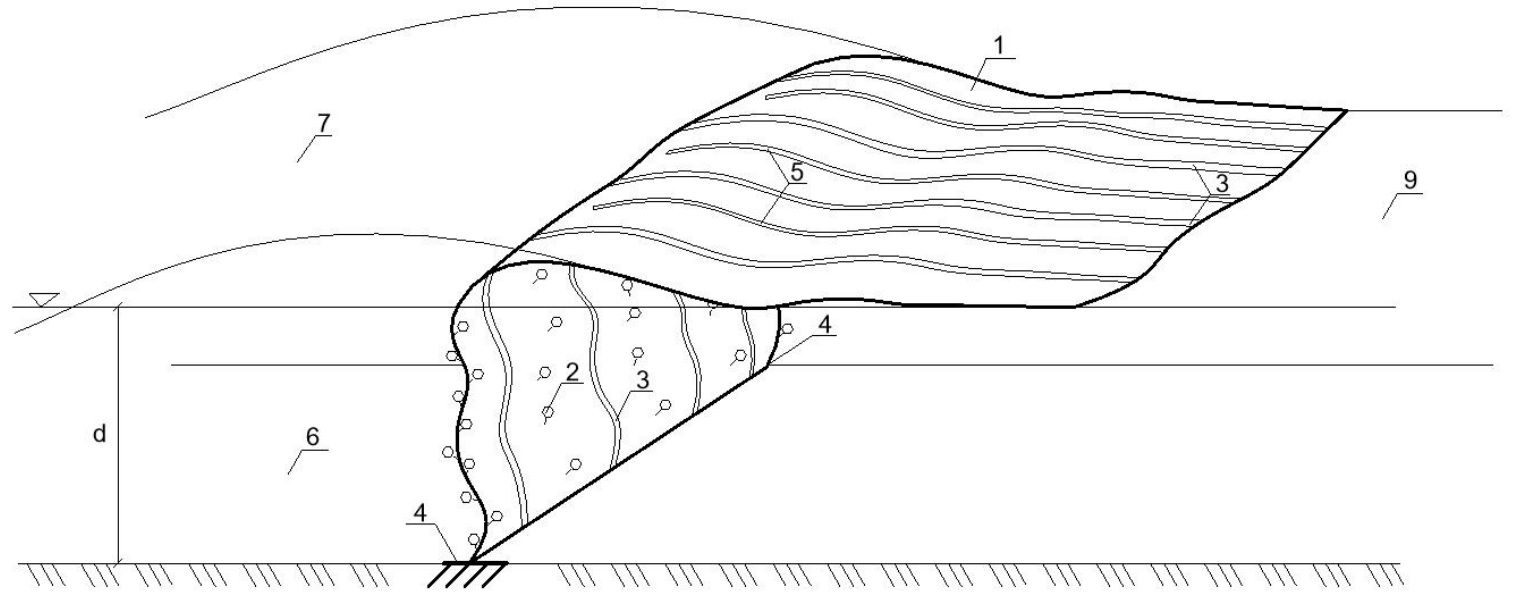

Fig. 1. The construction design of a floating flexible breakwater:

1 - floating wave-extinguishing structural element; 2 - floats; 3 - synthetic ropes with positive buoyancy; 4 - bracing device; 5 - synthetic ropes, which consist of a material whose density is approximately equal to the density of sea water; 6 - bottom; 7 - wavy water surface; 8 - elliptical orbits; 9 - calm surface of the water 
The construction design of a floating flexible protective structure consists of a floating waveextinguishing structural element 1, made in the form of a self, one-piece cloth of non-woven synthetic material with positive buoyancy. The total height of the canvas consists of the sum of the water depth at the installation site, taking into account the maximum water level of $4 \%$ of reliability in the construction area, and half the average wavelength in the storm system, repeated once in 25 years at the place of operation of the breakwater. A three-dimensional model of the construction design of a floating flexible protective structure is shown in Fig. 2.

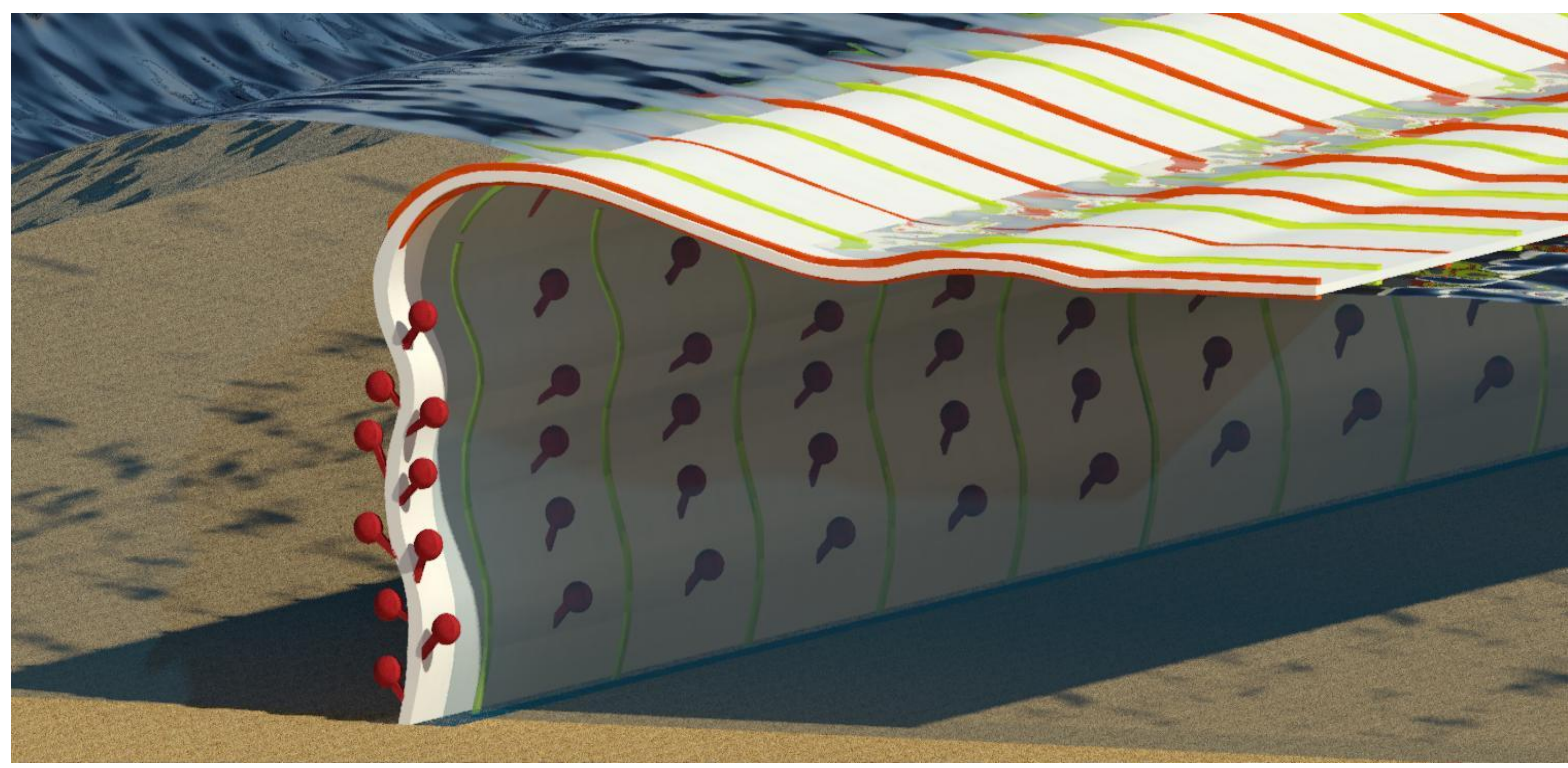

Fig. 2. A three-dimensional model of the construction design of a floating flexible protective structure

The vertical part of the wave-extinguishing element 1 is additionally equipped with floats 2 , to create additional buoyancy and roughness over its entire area, which contributes to the dissipation of the energy of wind waves (Fig. 3). The floating wave-extinguishing element 1 is strengthened along the entire length by synthetic ropes 3 . The density of the material of these ropes is less than the density of water. Thus, the ropes, in addition to increasing the strength of the material and buoyancy, also increase its roughness. The lower part of the vertical wave-extinguishing element 1 is connected by synthetic ropes 3 with a bracing device 4 located on the seabed 6 along the entire length of the flexible floating breakwater. The horizontal part of the wave-extinguishing element is also strengthened by synthetic ropes 5 , the density of the material of which is approximately equal to the density of sea water.

A floating flexible breakwater works as follows (Fig. 4). Wind waves 7 on a wavy surface meet wave-extinguishing element 1 on their extinguishing path. As known, water particles in a wave with a ratio of water depth $d$ to wavelength $\lambda,(d / \lambda<0,5)$ move along elliptical orbits 8 decaying with water depth. In this case, vertical $V_{z}$ and horizontal $V_{x}$ the projections of the orbital velocities decrease with distance from the quiet level 9. In shallow water, the vertical projection of the orbital velocity $\mathrm{V}_{\mathrm{Z}}$ tends to zero throughout the water depth, and the water particles near the bottom 6 make reciprocating movements, the speed of which is determined by the formula (1) [19]:

$$
V_{x}=\frac{1}{2} \frac{h}{d} \sqrt{g d},
$$

where $\mathrm{h}-$ is the wave height. 


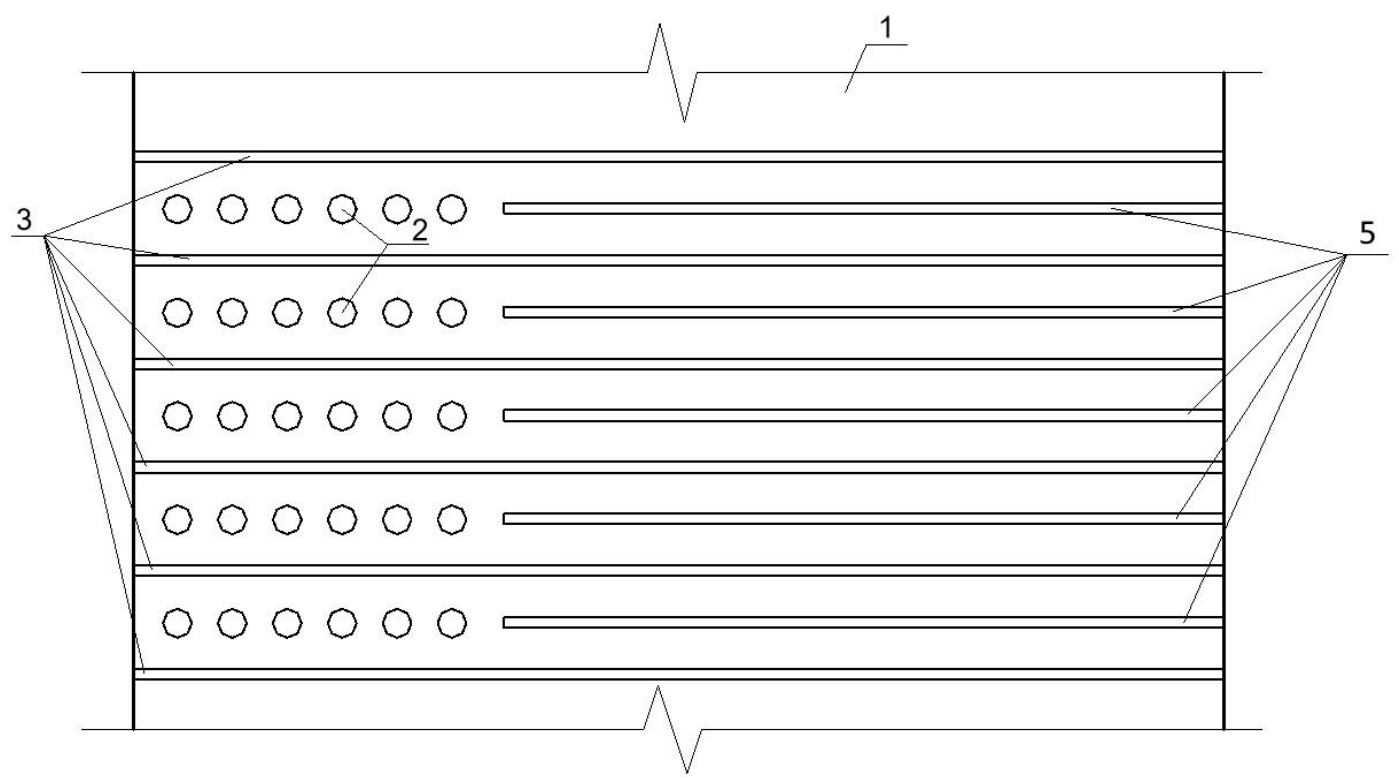

Fig. 3. Plan of a floating wave-extinguishing structural element:

1 - floating wave-extinguishing structural element; 2 - floats; 3 - synthetic ropes with positive buoyancy; 4 - bracing device; 5 - synthetic ropes, which consist of a material whose density is approximately equal to the density of sea water

The vertical part of the wave-extinguishing element 1, resists the wave pressure, deviating from the vertical in accordance with its depth distribution plot. Positive buoyancy of the vertical part of the canvas and the floats 2 located on it contribute to its return to the vertical initial position after the passage of the crests of the waves. In addition, the floats 2 create additional roughness for the dissipation of wave energy. Due to the deflections of the canvas (both its vertical and horizontal parts), there is a sharp decrease in the projections of wave velocities along the depth of the water. Considering the irregular and three-dimensional nature of sea waves, the horizontal part of the wave-extinguishing element along the entire length and area will make asynchronous oscillations. These oscillations will generate disturbances in the water environment, both in the water depth and on the water surface, which will also contribute to the effective suppression of the initial storm waves, significantly reducing their initial energy. Both the vertical and horizontal parts of the waveextinguishing element 1 will obstruct the process of moving wind waves on the water surface.

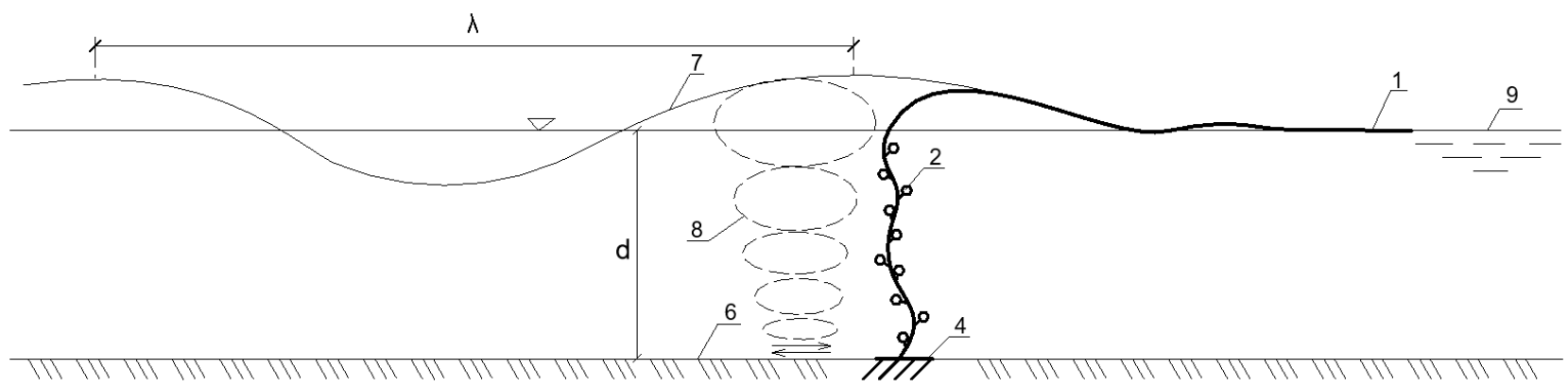

Fig. 4. Scheme of work of a flexible floating breakwater $(d / \lambda<0,5)$ :

1 - floating wave-extinguishing structural element; 2 - floats; 4 - bracing device; 6 - bottom;

7 - wavy water surface; 8 - elliptical orbits; 9 - calm surface of the water

Thus, the design of a floating flexible breakwater almost completely absorbs the energy of movement of water particles throughout the water depth, and behind a floating flexible breakwater along its entire length at a certain distance from it there will be a local, protected from sea waves, limited in area water area (Fig. 5). 


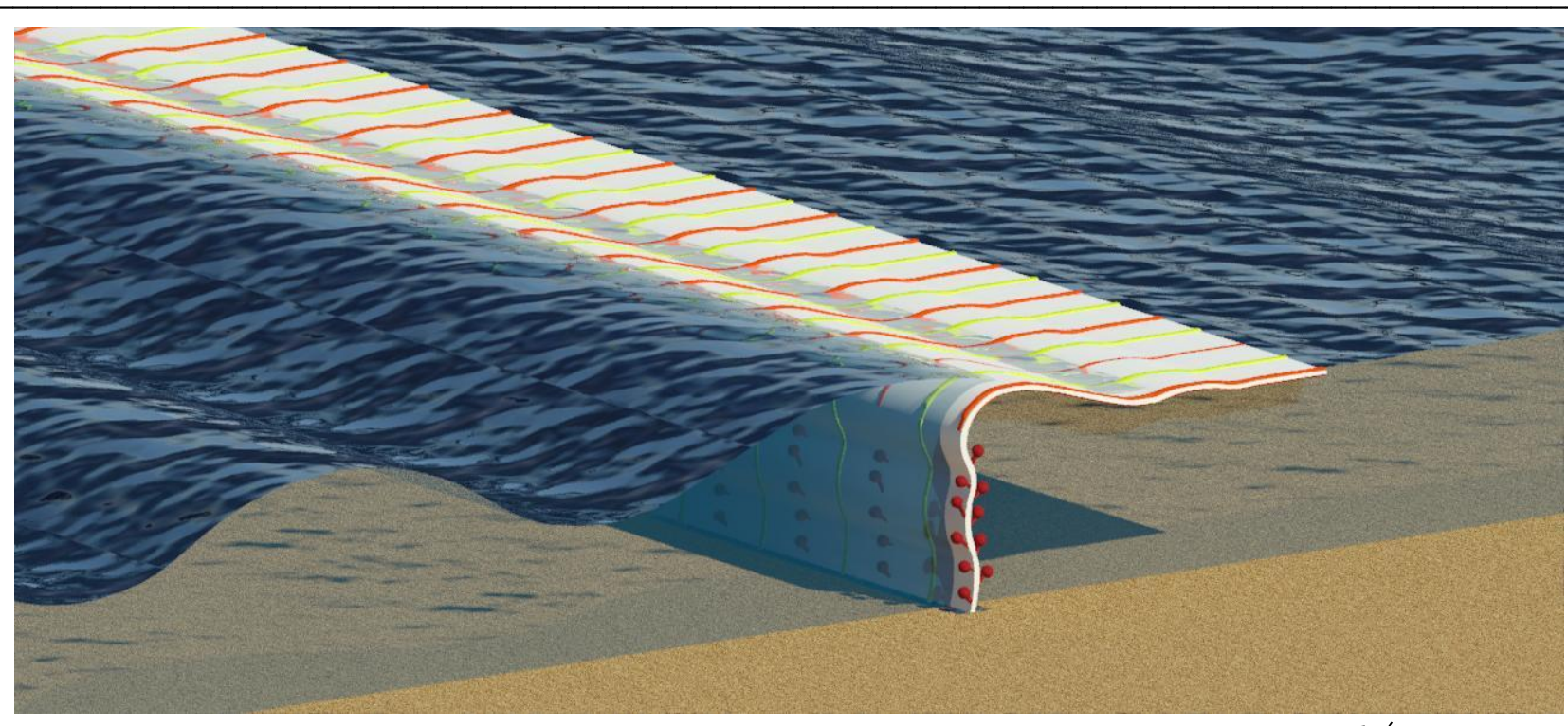

Fig. 5. The work of a flexible floating breakwater in the in shallow water zone $(d / \lambda<0,5)$

A flexible floating breakwater can also be used at more depths of water, for example, in the development of offshore hydrocarbon deposits, on the shelf of the seas, even in deep water zones. In this case, the vertical wave-extinguishing part of the breakwater can be limited to half the average wavelength in the storms system with a repeatability of once in 25 years. Moreover, bracing to the seabed can be carried out using synthetic ropes 3 (Fig. 6).

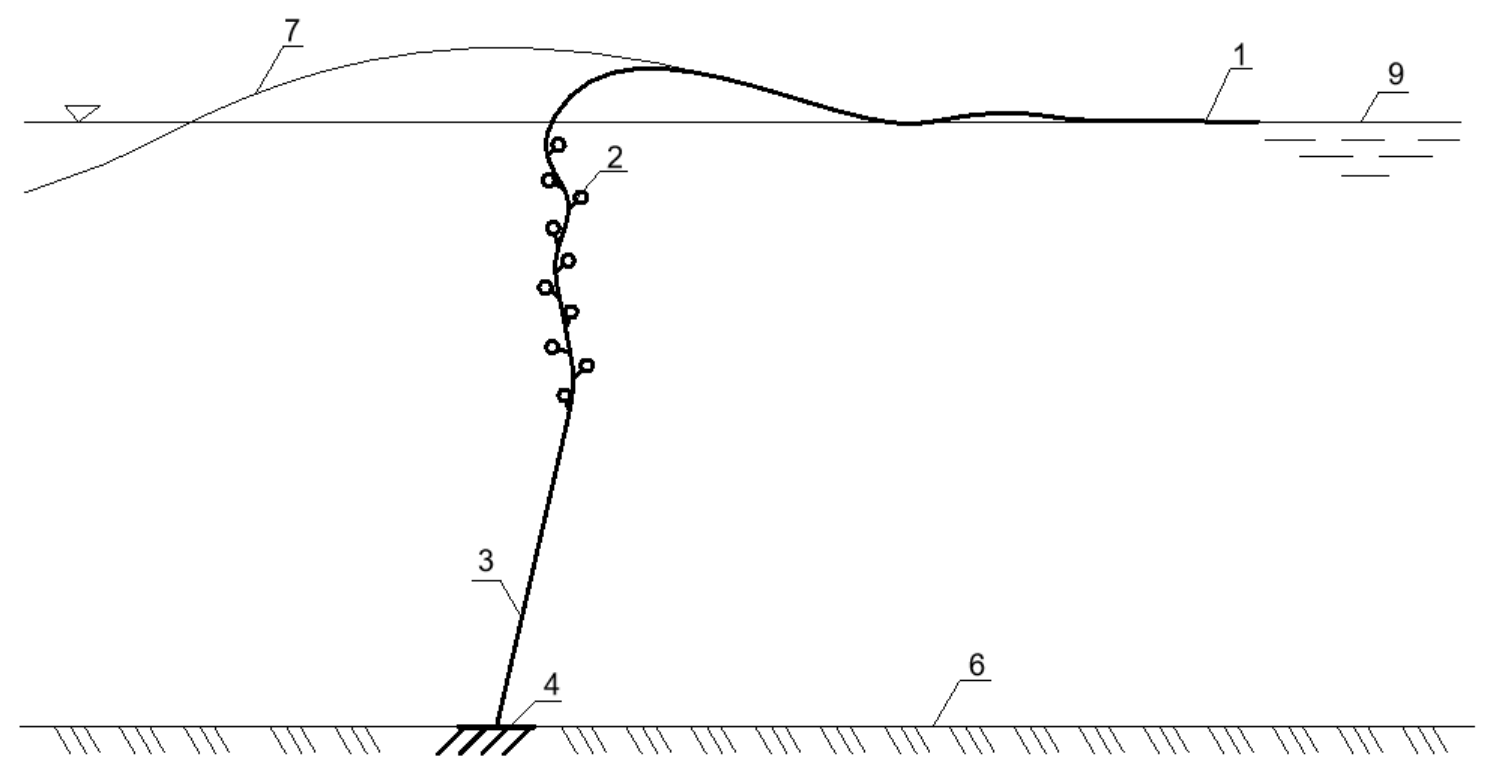

Fig. 6. The work of a flexible floating breakwater in the deep sea zone $(d / \lambda>0,5)$ :

1 - floating wave-extinguishing structural element; 2 - floats; 3 - synthetic ropes with positive buoyancy; 4 - bracing device; 6 - bottom; 7 - wavy water surface; 9 - calm surface of the water

The design of a floating flexible breakwater represented in this work is quick-build, mobile and relatively inexpensive. It can be rearranged and installed with the help of a floating crane of small capacity on the seabed in those places where the construction of hydraulic structures is being carried out in the open sea. In addition, a floating flexible breakwater can be successfully used in the water areas of estuaries, bays and reservoirs.

\section{Conclusions:}

1. The combination of the technical properties of floating and flexible protective structures in a new design solution will allow to overlap the wave front and effectively extinguish the energy of 
wind waves, not only on a wavy surface, but throughout the water depth.

2. The design of a floating flexible breakwater can be used in deep-sea, shallow and in surf zones.

3. A floating flexible breakwater is a fast-build protective structure, which significantly absorbs the energy of movement of water particles in the waves throughout the water depth, significantly reducing their parameters.

4. A floating flexible breakwater can be successfully used for temporary protection of limited water areas from wind waves, on which hydraulic structures of various purposes are being built in the open sea, as well as in estuaries, bays and reservoirs.

5. A floating flexible breakwater can also be used as temporary shore protection structures of the active type.

6. A floating flexible breakwater can be used as protective flexible spurs to protect against deposition of sea channels, including approach channels, both during their construction and operation.

7. The operational efficiency of a floating flexible breakwater in each specific case, taking into account the topography of the bottom, the protected area of the water area, the directions of the wave fronts, the calculated parameters of the waves, the sizes and characteristics of used materials, can be investigated and refined both in laboratory and in location conditions in the process of scientific support.

\section{References}

[1] O. K. Leontev, Osnovy heomorfolohyy morskykh berehov. Moscow: MHU, 1961.

[2] V.S. Dorofeev, S. Y. Rohachko, Vozdeistvye vetrovykh voln na hydrotekhnycheskye sooruzhenyia. Odessa: OHASA, 2012.

[3] Skvoznye i plavuchye volnolomy. [Online]. Available: https://studopedia.net/3_50054_skvoznie-i-plavuchie-volnolomi.html.

[4] S.V. Sysoev, Ustroistvo y oborudovanye morskykh portov. Vladyvostok: VMRK, 2013.

[5] Modulnye volnolomy. [Online]. Available: http://www.monolit$\mathrm{kb} . \mathrm{ru} / \mathrm{ru} / \mathrm{design} / \mathrm{sudostroenie} / 237 /$ nid=110\&a=entry.show.

[6] Wave attenuating device and method of attenuating waves. [Online]. Available: https://patents.google.com/patent/US3237414.

[7] Hasytel enerhii vody. [Online]. Available: http://uapatents.com/2-18665-gasitel-energivodi.html.

[8] Characteristics of floating breakwater. [Online]. Available: https://www.researchgate.net/figure/Characteristics-of-floating-breakwater_fig3_239735096.

[9] FDN Group-Brochure Dutch Floating Breakwaters \& Floating Structure Technology.Issuu, 2011. [Online]. Available: https://issuu.com/marinemegastore.com/docs/fdn-group-brochuredutch-floating-breakwaters---fl.

[10] Eugene P Richey, Floating Breakwater Field Experience, West Coast (Classic Reprint). Ketchikan: Forgotten Books, 1982.

[11] H.N. Smyrnov, Porty y portovye sooruzhenyia. Moskva: ASV, 2003.

[12] Composite structure. [Online]. Available: https://patents.google.com/patent/US3590585.

[13] Artificial seaweed device. [Online]. Available: https://patents.google.com/patent/US5961251.

[14] Hybkyi volnolom. [Online]. Available: https://findpatent.ru/patent/256/2564864.html.

[15] Yskusstvennyi substrat dlia hashenyia voln. [Online]. Available: http://www.freepatent.ru/patents/2406798.

[16] Artificial seaweed and method of accreting waterfronts. [Online]. Available: https://patents.google.com/patent/US4490071.

[17] Method and apparatus for building up beaches and protecting shorelines. [Online]. Available:https://docs.google.com/viewer?url=patentimages.storage.googleapis.com/pdfs /US4710057.pdf. 
[18] S.I. Rohachko, O. O. Pliasunova, "Plavuchyi hnuchkyi khvylelom", MPK E 02 B 3/06 (2006.01). № u201900441, Aug. 27, 2019.

[19] Y.O. Leontev, Prybrezhnaia dynamyka: volny, techenyia, potoky nanosov. Moskva: HEOS, 2001.

\title{
ПЛАВУЧА ГНУЧКА ОГОРОДЖУВАЛЬНА СПОРУДА
}

\author{
${ }^{1}$ Рогачко C.I., Д.т.н., професор, \\ rostasice@ukr.net, ORCID: 0000-0001-5201-5368 \\ ${ }^{1}$ Плясунова О.О., аспірант, \\ elena.margo56@gmail.com, ORCID: 0000-0003-0327-1861 \\ ${ }^{1}$ Одеський національний морський університет \\ вул. Мечникова, 34, м. Одеса, 65029, Україна
}

\begin{abstract}
Анотація. В гідротехнічному будівництві споруди різного призначення, а також берега морів, озер і водосховищ піддаються силовому впливу вітрових хвиль. Зниження інтенсивності цього впливу представляється важливою технічною проблемою, вирішення якої дозволить істотно збільшити термін служби стаціонарних морських споруд і знизити ступінь руйнування узбережжя, особливо тих ділянок, де знаходяться населені пункти і зони відпочинку.

У різних країнах світу запатентовано багато конструктивних рішень плавучих і гнучких хвилеломів, призначених для зменшення параметрів штормових хвиль. Вони можуть використовуватися для різних цілей в якості тимчасових споруд. В першу чергу це відноситься до зведення огороджувальних і берегозахисних споруд на незахищених акваторіях. Якщо акваторії багатьох портів нашої країни надійно захищені від проникаючого з моря вітрового хвилювання стаціонарними огороджувальними спорудами, то технічний стан багатьох берегозахисних споруд, що піддаються впливу штормових хвиль не можна охарактеризувати, як задовільний. Вони вимагають капітальної реконструкції. Узбережжя Чорного і Азовського морів великої протяжності необхідно захищати від руйнівного впливу вітрових хвиль i дрейфуючих крижаних полів в суворі зими рідкісної повторюваності різними типами берегозахисних споруд.
\end{abstract}

Облаштування морських родовищ вуглеводнів на шельфі Чорного моря пов'язане 3 будівництвом морських нафтогазопромислових гідротехнічних споруд на різних глибинах. Їх зведення буде здійснюватися також в умовах відкритого моря. При цьому втрати робочого часу, через несприятливі погодні умови, будуть суттєвими, що призведе до збільшення термінів будівництва, а значить і до фінансових витрат. 3 цієї причини розробка нових конструкцій нестаціонарних, швидкомонтованих хвилеломів для тимчасового захисту обмежених по площі акваторій є важливою інженерною задачею.

У даній роботі проаналізовані запатентовані в різних країнах конструкції плавучих і гнучких хвилеломів. На підставі цього аналізу була розроблена конструкція плавучого гнучкого хвилелому, яка може успішно застосовуватися для ефективного гасіння енергії вітрових хвиль на обмежених площах схвильованої штормової поверхні моря.

Дана конструкція плавучого гнучкого хвилелому захищена патентом нашої країни. 3 метою істотного зменшення параметрів вітрових хвиль вона може успішно застосовуватися при: будівництві стаціонарних захисних споруд; зведенні берегозахисних споруд різних типів; облаштуванні морських родовищ вуглеводнів на континентальному шельфі; захисту морських каналів від заносимості.

Ключові слова: плавуча гнучка огороджувальна споруда, плавучий хвилелом, гнучкий хвилелом, берегозахисні споруди, морські нафтогазопромислові гідротехнічні споруди, інноваційна конструкція, акваторія, підхідний канал, морський канал, вітрові хвилі. 


\title{
ПЛАВУЧЕЕ ГИБКОЕ ОГРАДИТЕЛЬНОЕ СООРУЖЕНИЕ
}

\author{
${ }^{1}$ Рогачко С.И., д.т.Н., профессор, \\ rostasice@ukr.net, ORCID: 0000-0001-5201-5368 \\ ${ }^{1}$ Плясунова Е.О., аспирант, \\ elena.margo56@gmail.com, ORCID: 0000-0003-0327-1861 \\ ${ }^{1}$ Одесский начиональный морской университет \\ ул. Мечникова, 34, м. Одеса, 65029, Украина
}

\begin{abstract}
Аннотация. В гидротехническом строительстве сооружения различного предназначения, а также берега морей, озер и водохранилищ подвергаются силовому воздействию ветровых волн. Снижение интенсивности этого воздействия представляется важной технической проблемой, решение которой позволит существенным образом увеличить срок службы стационарных морских сооружений и снизить степень разрушения побережий, особенно тех участков, где находятся населенные пункты и зоны отдыха.
\end{abstract}

В разных странах мира запатентовано много конструктивных решений плавучих и гибких волноломов, предназначенных для уменьшения параметров штормовых волн. Они могут использоваться для различных целей в качестве временных сооружений. В первую очередь это относится к возведению ограждающих и берегозащитных сооружений на незащищенных акваториях. Если акватории многих портов нашей страны надежно защищены от проникающего из моря ветрового волнения стационарными ограждающими сооружениями, то техническое состояние многих берегозащитных сооружений, подвергающихся воздействию штормовых волн нельзя охарактеризовать, как удовлетворительное. Они требуют капитальной реконструкции. Побережье Черного и Азовского морей большой протяженности необходимо защищать от разрушительного воздействия ветровых волн и дрейфующих ледовых образований в суровые зимы редкой повторяемости различными типами берегозащитных сооружений.

Обустройство морских месторождений углеводородов на шельфе Черного моря связано со строительством морских нефтегазопромысловых гидротехнических сооружений на разных глубинах. Их возведение будет осуществляться также в условиях открытого моря. При этом потери рабочего времени, при неблагоприятных погодных условиях, будут существенными, что приведет к увеличению сроков строительства, а значит и к финансовым затратам. По этой причине разработка новых конструкций нестационарных, быстровозводимых волноломов для временной защиты ограниченных по площади акваторий является важной инженерной задачей.

В настоящей работе проанализированы запатентованные в различных странах конструкции плавучих и гибких волноломов. На основании этого анализа была разработана конструкция плавучего гибкого волнолома, которая может успешно применяться для эффективного гашения энергии ветровых волн на ограниченных площадях взволнованной штормовой поверхности моря.

Данная конструкция плавучего гибкого волнолома защищена патентом нашей страны. С целью существенного уменьшения параметров ветровых волн она может успешно применяться при: строительстве стационарных оградительных сооружений; возведении берегозащитных сооружений различных типов; обустройстве морских месторождений углеводородов на континентальном шельфе; защите морских каналов от заносимости.

Ключевые слова: плавучее гибкое оградительное сооружение, плавучий волнолом, гибкий волнолом, берегозащитные сооружения, морские нефтегазопромысловые гидротехнические сооружения, инновационная конструкция, акватория, подходной канал, морской канал, ветровые волны.

Стаття надійшла до редакції 14.01.2020 